\title{
Pengaruh Jumlah Buku terhadap Produksi Bibit Ubi Jalar Varietas Cilembu dan Varietas Ungu
}

\section{Effect of Nodes Number on Sweetpotato Cutting Production of Cilembu and Purple Variety}

\section{Dwi Putri Maulida dan Asep Setiawan*}

Departemen Agronomi dan Hortikultura, Fakultas Pertanian, Institut Pertanian Bogor (Bogor Agricultural University), Jl. Meranti, Kampus IPB Darmaga, Bogor 16680, Indonesia Telp. \& Faks.62-251-8629353 e-mail agronipb@indo.net.id

*Penulis Korespondensi : asetiawan_agh@yahoo.com

Disetujui : 15 Januari 2018 / Published Online 23 Januari 2018

\begin{abstract}
Research aimed to obtain information on the effect of nodes number on sweet potato cutting production. The experiments were performed at the Experimental Garden Leuwikopo IPB from January 2016 to April 2016. The experiment was arranged in a randomized complete Design Group (RCBD) twofactor design with three replications. The first factor is the number of nodes consists of three nodes, four nodes and five nodes. The second factor is a variety that consists of Cilembu varieties and Purple varieties. Parameters measured were stem length, the length of primary branch, secondary branch length, number of primary branches, number of secondary branches, number of seeds the size of $25 \mathrm{~cm}, 20 \mathrm{~cm}$ number of seeds, number of seeds size $15 \mathrm{~cm}$, total tuber weight. The four nodes treatment produce longer stem griow rates and the five nodes treatments produced longer primary branch compared to other treatments, however the number of produced cutting by all treatments is similar. Purple varieties produced longer secondary branches and number of cuttings than Cilembu variety but the amount of produced cutting is similar.
\end{abstract}

Keywords: tips cuttings, sweet potato, cutting multiplication

\begin{abstract}
ABSTRAK
Penelitian ini dilakukan bertujuan untuk mendapatkan informasi pengaruh jumlah buku terhadap produksi bibit ubi jalar. Percobaan dilakukan di Kebun Percobaan Leuwikopo IPB mulai dari bulan Januari 2016 hingga April 2016. Percobaan disusun dalam Rancangan Kelompok Lengkap Teracak (RKLT) dua faktor dengan tiga ulangan. Faktor pertama adalah jumlah buku yang terdiri dari 3 buku, 4 buku dan 5 buku. Faktor kedua adalah varietas yang terdiri dari varietas Cilembu dan Ungu. Parameter yang diamati adalah panjang batang, panjang cabang primer, panjang cabang sekunder, jumlah cabang primer, jumlah cabang sekunder, jumlah bibit berukuran $25 \mathrm{~cm}$, jumlah bibit berukuran $20 \mathrm{~cm}$, jumlah bibit berukuran 15 $\mathrm{cm}$, bobot umbi total. Perlakuan 4 buku menghasilkan pertambahan panjang batang yang lebih cepat dan perlakuan 5 buku menghasilkan panjang cabang primer yang lebih panjang dari pada perlakuan lainnya namun jumlah stek yang dihasilkan oleh ketiga perlakuan relatif sama. Varietas ungu menghasilkan cabang sekunder lebih panjang dan jumlah stek lebih banyak dibandingkan Cilembu.
\end{abstract}

Kata kunci : stek pucuk, ubi jalar, perbanyakan cepat 


\section{PENDAHULUAN}

Ubi jalar (Ipomoea batatas L.) merupakan salah satu komoditas umbi-umbian yang terkenal di kalangan masyarakat Indonesia. Masalah utama yang dihadapi dalam kegiatan usaha ubi jalar yaitu rendahnya produksi yang disebabkan oleh pelaksanaan teknik budidaya yang belum sempurna (Harjadi, 1996). Bibit yang bermutu merupakan salah satu kunci keberhasilan budidaya ubi jalar karena bibit merupakan sarana produksi utama penghasil ubi jalar. Banyak penelitian menunjukkan bahwa penggunaan bibit bagian pucuk sebagai bibit akan mengasilkan produktivitas yang lebih tinggi daripada bibit non pucuk. Salah satu peningkatan produktivitas tanaman ubi jalar dipengaruhi oleh penggunaan bibit yang baik. Luasan 1 ha dengan jarak tanam $25 \mathrm{~cm}$ x $100 \mathrm{~cm}$ membutuhkan bibit sebanyak 40 000 bibit ubi jalar (Soemarno, 1985). Mengingat banyaknya bibit yang dibutuhkan maka upaya memproduksi bibit secara lebih efisien perlu dilakukan.

Menurut Santoso et al. (2008) pertumbuhan stek hidup terbaik pada jarak pagar diperoleh pada stek dengan panjang 20-30 cm dan diameter $2.0-2.4 \mathrm{~cm}$. Terdapat kontribusi terkait dengan panjang stek yaitu perbedaan akumulasi karbohidrat pada bagian bawah stek dan jumlahnya akan optimal untuk pembentukan akar pada stek yang panjang dibandingkan stek pendek (Hartmann et al., 2002). Namun pada aspek teknis, penggunaan stek panjang memerlukan bahan tanaman yang lebih banyak sedangkan pada kondisi saat ini ketersediaannya sangat terbatas sehingga penggunaan stek pendek akan lebih menguntungkan (Wargiono, 2007).

Teknik yang umum digunakan petani dalam memproduksi bibit adalah dengan cara menanam satu stek bibit sumber berukuran 25-30 $\mathrm{cm}$ dan memanen stek ketika tanaman berumur 2 bulan (Wargiono, 2007). Teknik ini mampu menghasilkan 4-6 bibit dari satu bibit sumber. Menurut Tinuk (2012) cara tanam dengan membenamkan empat ruas batang ke tanah berpengaruh terhadap panjang dan diameter sulur. Upaya menghasilkan bibit secara lebih cepat dapat dilakukan dengan teknik rapid multiplication, dimana dalam teknik ini bibit yang ditanam adalah bibit dengan 2 atau 3 buku. Menggunakan teknik ini kebutuhan bibit sumber dapat dikurangi karena hanya dibutuhkan bibit dengan 2-3 buku dibanding cara konvensional yang biasanya menggunakan 5 buku. Bibit sumber yang lebih pendek dengan upaya memproduksi bibit ubijalar diharapkan dapat dilakukan dengan lebih cepat karena bibit sumbernya telah ditanam saat memiliki buku kurang dari 5. Penelitian ini bertujuan untuk mengkaji pengaruh jumlah buku terhadap produksi bibit.

\section{METODE PENELITIAN}

Penelitian ini dilaksanakan di Kebun Percobaan Leuwikopo, IPB, Darmaga, Bogor berlangsung pada bulan Januari sampai April 2016. Faktor pertama adalah bibit ubi jalar yang berumur 2 bulan dengan tiga buku, empat buku dan lima buku. Faktor kedua berupa varietas yaitu varietas Cilembu dan varietas Ungu. Penelitian ini menggunakan Rancangan Faktorial Kelompok Lengkap Teracak (RKLT) dengan dua faktor yaitu faktor pertama adalah jumlah buku dan faktor kedua adalah varietas. Percobaan dilakukan sebanyak tiga ulangan dengan 18 petak satuan percobaan.

Bahan lain yang digunakan antara lain pupuk kandang dengan dosis 10 ton $\mathrm{ha}^{-1}$, kapur pertanian dengan dosis $1 \mathrm{~kg} \mathrm{ha}^{-1}$, Rotoon $\mathrm{F}$ sebanyak $6 \mathrm{~kg} \mathrm{ha}^{-1}$, pupuk tunggal Urea $100 \mathrm{~kg}$ $\mathrm{ha}^{-1}$, SP-36 $50 \mathrm{~kg} \mathrm{ha}^{-1}$, dan, KCl $75 \mathrm{~kg} \mathrm{ha}^{-1}$. Pengendalian hama dan penyakit dilakukan pada 6 MST menggunakan insektisida Decis dengan dosis $2 \mathrm{ml} \mathrm{l}^{-1}$ dan menggunakan Carbofuran 3G sebanyak $5 \mathrm{~kg} \mathrm{ha}^{-1}$. Alat yang digunakan berupa meteran, alat cutting, alat dan mesin pertanian, plastik, label, paku, dan bambu.

Pelaksanaan penelitian dimulai dari persiapan bibit, persiapan tanam, penanaman dan pemupukan, pemeliharaan dan pengamatan percobaan. Persiapan bibit dilakukan dengan teknik perbanyakan tanaman ubi jalar yang dilakukan menggunakan stek pucuk. Bibit yang didapatkan berupa stek berumur 2 bulan. Setelah itu persiapan tanam dimulai dengan pengolahan tanah secara manual dengan membersihkan gulma yang terdapat di lahan sampai keadaan bebas gulma. Tanah yang sudah di olah dibuat petakan sebanyak 18 petak dengan ukuran 5 x 4 $\mathrm{m}$. Guludan akan dibuat dengan lebar $50 \mathrm{~cm}$, tinggi $25 \mathrm{~cm}$, jarak antar guludan $50 \mathrm{~cm}$ dan panjang guludan $400 \mathrm{~cm}$ setelah guludan dibuat, lahan diberi pupuk kandang dengan dosis 10 ton $\mathrm{ha}^{-1}$ dan kapur pertanian dengan dosis $1 \mathrm{~kg} \mathrm{ha}^{-1}$ sebelum dilakukan penanaman. Penanaman dilakukan dengan jarak tanaman 100 × $25 \mathrm{~cm}$.

Penanaman bibit ubi jalar dilakukan menggunakan sumber bibit yang berasal dari stek pucuk. Penanaman dilakukan di tengah guludan dengan jarak antar guludan $50 \mathrm{~cm}$. Sumber bibit didapatkan dari dua varietas yaitu varietas Cilembu (V1) dan varietas Ungu (V2). Penanaman dilakukan dengan 3 perlakuan tanam dengan 3 buku (B3), perlakuan 4 buku (B4), dan 5 
buku (B5) dengan rincian penanaman 2 buku di bawah permukaan tanah. Sebelum ditanam, stek pucuk direndam menggunakan Rotoon $F$ agar merangsang pertumbuhan akar ketika sudah ditanam. Aplikasi pupuk dilakukan sebanyak dua kali yaitu aplikasi pertama pada 2 Minggu Setelah Tanam dengan memberikan 1 dosis Urea, 1 dosis SP-36 dan $1 / 2$ dosis $\mathrm{KCl}$. Aplikasi kedua yaitu pada 5 MST dengan memberikan 1 dosis urea.

Pemeliharaan yang dilakukan antara lain penyiangan gulma, pembumbunan, dan pengendalian hama dan penyakit. Penyiangan gulma dilakukan secara manual menggunakan cangkul atau kored. Pembumbunan dilakukan agar tidak terjadi keretakan tanah dan pembumbunan dapat menggemburkan tanah di sekitar perakaran agar umbi terbentuk dengan sempurna sekaligus menutupi umbi-umbi yang terbuka. Pengendalian hama dan penyakit dilakukan pemberian insektisida Carbofuran 3G dengan dosis $5 \mathrm{~kg} \mathrm{ha}^{-1}$ yang dilakukan pada awal pertanaman dan penyemprotan insektisida Decis dengan dosis 2 $\mathrm{ml} / \mathrm{l}$ yang diberikan pada $6 \mathrm{MST}$.

Pengamatan dilakukan terhadap tanaman contoh dari tiap petak percobaan yang dilakukan pada umur 2 MST sampai 7 MST. Pengamatan berupa pengamatan vegetatif, produksi bibit dan produksi umbi.

1. Peubah vegetatif yang diamatai

- Panjang batang dilakukan dengan cara diukur mulai dari pangkal batang utama sampai ujung batang

- Panjang cabang primer dilakukan dengan cara diukur dari tempat tumbuh batang utama sampai ujung cabang primer

- Panjang cabang sekunder dilakukan dengan cara diukur dari tempat tumbuh batang primer sampai ujung cabang sekunder

- Jumlah cabang sekunder dilakukan dengan cara diamati banyaknya cabang yang tumbuh dari buku cabang primer

- Jumlah cabang primer dilakukan dengan cara diamati banyaknya cabang yang tumbuh dari buku cabang utama

2. Parameter produksi bibit yang diamati

- Jumlah bibit berukuran $25 \mathrm{~cm}$ dilakukan dengan menghitung jumlah bibit yang berukuran $25 \mathrm{~cm}$ yang diambil dari stek pucuk dan stek batang tanaman contoh setiap ulangan

- Jumlah bibit berukuran $20 \mathrm{~cm}$ Jumlah bibit $20 \mathrm{~cm}$ dilakukan dengan menghitung bibit yang berukuran $20 \mathrm{~cm}$ yang diambil dari stek pucuk dan stek batang tanaman contoh setiap ulangan
- Jumlah bibit berukuran $15 \mathrm{~cm}$ dilakukan dengan cara menghitung bibit yang berukuran $15 \mathrm{~cm}$ yang diambil dari stek pucuk dan stek batang tanaman contoh setiap ulangan

3. Parameter produksi umbi yang diamati

- Bobot umbi total dihitung dari total bobot umbi tanaman contoh dan tanaman per petak

Data hasil pengamatan dianalisis dengan sidik ragam menggunakan Software SAS 9.1 untuk mengetahui pengaruh perlakuan, apabila perlakuan berpengaruh nyata dilakukan uji lanjut DMRT dengan taraf $\alpha=5 \%$. Untuk analisis korelasi menggunakan software Minitab 16.

\section{HASIL DAN PEMBAHASAN}

\section{Kondisi Umum}

Kondisi umum di kebun Percobaan Leuwikopo IPB bogor yaitu suhu rata-rata $27.1{ }^{\circ} \mathrm{C}$ dengan curah hujan rata-rata yaitu $467 \mathrm{~mm}_{\text {bulan }}{ }^{-1}$ dan kelembaban rata-rata $84 \%$. Kondisi di wilayah Dramaga kurang cocok untuk pertanaman ubi jalar. Menurut Kay (1973) tanaman ubi jalar cocok dilakukan di daerah tropis dan lembab dengan suhu $21-27{ }^{\circ} \mathrm{C}$ dan curah hujan $750-1.500$ mm bulan ${ }^{-1}$.

Gulma yang terdapat pada petak percobaan adalah jenis gulma berdaun lebar seperti Mimosa sp., gulma kelompok teki-tekian yaitu Cyperus rotundus, dan gulma berdaun sempit seperti Roetboellia exaltata. Pengendalian gulma tersebut dilakukan secara manual dengan melakukan penyiangan. Hama yang sering ditemui pada lahan penelitian yaitu belalang (Valanga sp.) dan penggerek batang (Omphisia anastomasalis), Hama yang menyerang tanaman ubi jalar tidak seluruhnya merusak pertumbuhan vegetatif maupun generatif. Keadaan tanaman masih bisa untuk di panen dan penyakit yang ditimbulkan juga tidak banyak.

Hasil rekapitulasi sidik ragam pengaruh jumlah buku, varietas, interaksi antara keduanya terhadap pertumbuhan vegetatif, hasil panen bibit, dan hasil panen umbi disajikan pada Tabel 1. Hasil rekapitulasi sidik ragam menunjukkan nilai KK yang beragam. Nilai KK menunjukkan tingkat ketepatan pada perlakuan yang diperbandingkan dan merupakan indeks yang baik dari keadaan percobaan (Gomez dan Gomez, 2007). Nilai KK tertinggi terdapat pada peubah panjang primer pada umur 3 MST dengan hasil $23.67 \%$ dan KK terendah diperoleh pada peubah panjang cabang sekunder umur 7 MST dengan hasil $11.85 \%$. 
Tabel 1. Rekapitulasi sidik ragam pengaruh jumlah buku, varietas dan interaksi antara jumlah buku dan varietas terhadap pertumbuhan vegetatif, hasil panen bibit, dan hasil umbi

\begin{tabular}{|c|c|c|c|c|c|}
\hline Peubah & $\begin{array}{l}\text { Umur } \\
\text { (MST) }\end{array}$ & umlah Buku (JB) & $\begin{array}{c}\text { Varietas } \\
\text { (V) }\end{array}$ & $\mathrm{JB} * \mathrm{~V}$ & $\mathrm{KK}(\%)$ \\
\hline \multicolumn{6}{|l|}{ a. Pertumbuhan vegetatif } \\
\hline \multirow[t]{6}{*}{ Panjang batang $(\mathrm{cm})$} & 2 & $8.56^{* *}$ & $2.13^{\mathrm{tn}}$ & $0.17^{\mathrm{tn}}$ & 17.87 \\
\hline & 3 & $2.98 *$ & $1.38^{\mathrm{tn}}$ & $1.17^{\mathrm{tn}}$ & 20.74 \\
\hline & 4 & $15.23 * *$ & $10.70 * *$ & $0.28^{\mathrm{tn}}$ & 12.06 \\
\hline & 5 & $12.71 * *$ & $2.33^{\text {tn }}$ & $2.82^{\text {tn }}$ & 11.99 \\
\hline & 6 & $11.00 * *$ & $0.04^{\mathrm{tn}}$ & $1.86^{\mathrm{tn}}$ & 13.17 \\
\hline & 7 & $6.49 *$ & $0.09^{\operatorname{tn}}$ & $3.86^{\mathrm{tn}}$ & 14.57 \\
\hline \multirow[t]{5}{*}{ Panjang cabang primer $(\mathrm{cm})$} & 3 & $3.24 *$ & $13.68 * *$ & $0.69^{\operatorname{tn}}$ & 23.67 \\
\hline & 4 & $15.23 * *$ & $10.70 * *$ & $0.28^{\mathrm{tn}}$ & 12.06 \\
\hline & 5 & $12.71 * *$ & $2.33^{\mathrm{tn}}$ & $2.82^{\mathrm{tn}}$ & 11.99 \\
\hline & 6 & $11.00 * *$ & $0.04^{\mathrm{tn}}$ & $1.86^{\mathrm{tn}}$ & 13.17 \\
\hline & 7 & $6.49 *$ & $0.09^{\text {th }}$ & $3.86^{\mathrm{tn}}$ & 14.57 \\
\hline \multirow[t]{5}{*}{ Panjang cabang sekunder $(\mathrm{cm})$} & 3 & $1.86^{\mathrm{tn}}$ & $2.57^{\mathrm{tn}}$ & $0.49^{\text {tn }}$ & 23.36 \\
\hline & 4 & $3.07^{\mathrm{tn}}$ & $3.48^{\mathrm{tn}}$ & $0.06^{\mathrm{tn}}$ & 21.72 \\
\hline & 5 & $2.25^{\mathrm{tn}}$ & $10.99 * *$ & $0.22^{\mathrm{tn}}$ & 17.11 \\
\hline & 6 & $0.17^{\mathrm{tn}}$ & $10.84 * *$ & $0.26^{\mathrm{tn}}$ & 15.74 \\
\hline & 7 & $2.58^{\mathrm{tn}}$ & $32.12 * *$ & $0.43^{\operatorname{tn}}$ & 11.85 \\
\hline \multicolumn{6}{|l|}{ Jumlah cabang primer (cabang/tanaman) } \\
\hline & 3 & $3.43^{\text {tn }}$ & $16.49 * *$ & $3.94^{\text {tn }}$ & 17.28 \\
\hline & 4 & $3.21^{\mathrm{tn}}$ & $9.93 *$ & $2.06^{\mathrm{tn}}$ & 18.21 \\
\hline & 5 & $0.25^{\mathrm{tn}}$ & $4.27^{\mathrm{tn}}$ & $0.33^{\mathrm{tn}}$ & 17.33 \\
\hline & 6 & $1.04^{\mathrm{tn}}$ & $10.34 * *$ & $0.96^{\mathrm{tn}}$ & 18.84 \\
\hline & 7 & $2.03^{\operatorname{tn}}$ & $3.49^{\operatorname{tn}}$ & $2.03^{\operatorname{tn}}$ & 18.20 \\
\hline \multicolumn{6}{|l|}{ Jumlah cabang sekunder (cabang/tanaman) } \\
\hline & 3 & $1.27^{\mathrm{tn}}$ & $0.27^{\mathrm{tn}}$ & $1.27^{\mathrm{tn}}$ & $14.98^{(\mathrm{a})}$ \\
\hline & 4 & $1.81^{\mathrm{tn}}$ & $0.02^{\mathrm{tn}}$ & $1.11^{\mathrm{tn}}$ & $16.16^{(\mathrm{a})}$ \\
\hline & 5 & $1.55^{\mathrm{tn}}$ & $0.42^{\mathrm{tn}}$ & $1.83^{\text {tn }}$ & $15.48^{(\mathrm{a})}$ \\
\hline & 6 & $2.44^{\mathrm{tn}}$ & $2.11^{\mathrm{tn}}$ & $0.57^{\mathrm{tn}}$ & $13.64^{(\mathrm{a})}$ \\
\hline & 7 & $0.41^{\mathrm{tn}}$ & $1.89^{\operatorname{tn}}$ & $3.14^{\text {tn }}$ & 15.50 \\
\hline \multicolumn{6}{|l|}{ b. Hasil panen bibit } \\
\hline Jumlah bibit ukuran $25 \mathrm{~cm}$ (stek/tanaman) & & $3.21^{\mathrm{tn}}$ & $4.68^{\mathrm{tn}}$ & $6.96^{* *}$ & $12.48^{(\mathrm{a})}$ \\
\hline Jumlah bibit ukuran $20 \mathrm{~cm}$ (stek/tanaman) & & $0.23^{\text {tn }}$ & $21.36^{* *}$ & $2.12^{\mathrm{tn}}$ & $14.12^{(\mathrm{a})}$ \\
\hline Jumlah bibit ukuran $15 \mathrm{~cm}$ (stek/tanaman) & & $0.55^{\mathrm{tn}}$ & $0.02^{\text {tn }}$ & $0.24^{\mathrm{tn}}$ & $16.09^{(a)}$ \\
\hline \multicolumn{6}{|l|}{ c. Hasil panen umbi ${ }^{(b)}$} \\
\hline Umbi total per petak (kg/petak) & & $0.20^{\operatorname{tn}}$ & $0.33^{\text {tn }}$ & $0.39^{\mathrm{tn}}$ & $13.42^{(\mathrm{a})}$ \\
\hline
\end{tabular}

\section{Evaluasi terhadap Karakter Vegetatif}

Evaluasi karakter vegetatif dilakukan pada saat awal fase vegetatif dan akhir fase vegetatif tanaman. Peubah vegetatif yang diamati berupa panjang batang, panjang cabang primer, panjang cabang sekunder, jumlah cabang primer dan jumlah cabang sekunder.

Panjang Batang. Panjang batang merupakan ukuran tanaman yang sering diamati dan sebagai indikator pertumbuhan maupun sebagai parameter yang digunakan untuk mengukur pengaruh lingkungan atau perlakuan yang ditetapkan. Menurut Marleni (2010) menunjukkan bahwa semakin banyak jumlah buku stek maka panjang stek semakin panjang. Tabel 2 menunjukkan bahwa pada setiap periode pengamatan, perlakuan 5 buku memiliki panjang batang lebih panjang dibandingkan perlakuan lainnya. Selisih atau delta panjang batang saat pengamatan 7 MST dan 2 MST pada perlakuan 3, 4 dan 5 buku berturut-turut adalah $6.86 \mathrm{~cm}, 8.3$ $\mathrm{cm}$, dan $8.17 \mathrm{~cm}$. Hal ini mengindikasikan bahwa laju pertumbuhan panjang batang pada perlakuan 3 buku relatif lebih rendah dibandingkan dua perlakuan lainnya. Menurut Hartmann et al (1997) 
dengan jumlah buku yang berbeda, cadangan makanan pada kedua stek akan berbeda, stek yang lebih besar akan lebih cepat tumbuh dengan mendistribusikan cadangan makanan.

Tabel 2. Pengaruh jumlah buku terhadap panjang batang

\begin{tabular}{cccccccc}
\hline \multirow{2}{*}{ Jumlah Buku } & \multicolumn{7}{c}{ Umur } \\
\cline { 2 - 7 } & 2 MST & 3 MST & 4 MST & 5 MST & 6 MST & 7 MST & 7-2 MST \\
\hline & ------------- & \\
3 Buku & $7.17 \mathrm{~b}$ & $10.77 \mathrm{~b}$ & $11.10 \mathrm{~b}$ & $13.07 \mathrm{~b}$ & $13.60 \mathrm{~b}$ & $14.03 \mathrm{~b}$ & 6.86 \\
$4 \mathrm{Buku}$ & $8.50 \mathrm{~b}$ & $12.03 \mathrm{a}$ & $12.87 \mathrm{~b}$ & $15.22 \mathrm{~b}$ & $15.65 \mathrm{~b}$ & $16.80 \mathrm{a}$ & 8.30 \\
$5 \mathrm{Buku}$ & $10.90 \mathrm{a}$ & $14.33 \mathrm{a}$ & $16.17 \mathrm{a}$ & $18.47 \mathrm{a}$ & $19.30 \mathrm{a}$ & $19.07 \mathrm{a}$ & 8.17 \\
\hline
\end{tabular}

keterangan : angka yang diikuti oleh huruf yang sama pada kolom yang sama tidak berbeda nyata pada uji lanjut DMRT 5\%.

Tabel 3 menunjukkan perbedaan antar varietas berpengaruh terhadap panjang batang hanya pada pengamatan 4 MST. Hal ini mengindikasikan bahwa laju pertumbuhan bibit kedua varietas relatif sama.

Tabel 3. Pengaruh varietas terhadap panjang batang

\begin{tabular}{ccccccc}
\hline \multirow{2}{*}{ Varietas } & \multicolumn{5}{c}{ Umur } \\
\cline { 2 - 7 } & 2 MST & 3 MST & 4 MST & 5 MST & 6 MST & 7 MST \\
\hline \multirow{2}{*}{ Cilembu } & $8.31 \mathrm{a}$ & $-11.67 \mathrm{a}$ & $12.13 \mathrm{~b}$ & $14.91 \mathrm{a}$ & $16.09 \mathrm{a}$ & $16.80 \mathrm{a}$ \\
Ungu & $9.40 \mathrm{a}$ & $13.09 \mathrm{a}$ & $14.62 \mathrm{a}$ & $16.26 \mathrm{a}$ & $16.28 \mathrm{a}$ & $16.47 \mathrm{a}$
\end{tabular}

keterangan : angka yang diikuti oleh huruf yang sama pada kolom yang sama tidak berbeda nyata pada uji lanjut DMRT 5\%.

Panjang Cabang Primer. Cabang primer merupakan cabang yang tumbuh pada batang utama. Panjang cabang primer diukur dari tempat tumbuh 'tumbuh batang utama sampai ujung cabang primer. Tabel 4 menunjukkan bahwa setiap periode pertumbuhan panjang cabang primer perlakuan 5 buku memiliki panjang cabang primer lebih panjang dibandingkan perlakuan lainnya.

Tabel 4. Pengaruh jumlah buku terhadap panjang cabang primer

\begin{tabular}{|c|c|c|c|c|c|}
\hline \multirow{2}{*}{ Jumlah Buku } & \multicolumn{5}{|c|}{ Umur } \\
\hline & $3 \mathrm{MST}$ & $4 \mathrm{MST}$ & $5 \mathrm{MST}$ & $6 \mathrm{MST}$ & $7 \mathrm{MST}$ \\
\hline & \multicolumn{5}{|c|}{ |---------------------------------------cm------------------------------------ } \\
\hline 3 Buku & $6.75 \mathrm{a}$ & $11.10 \mathrm{~b}$ & $13.07 \mathrm{~b}$ & $13.60 \mathrm{~b}$ & $14.03 \mathrm{~b}$ \\
\hline 4 Buku & $5.18 \mathrm{a}$ & $12.87 \mathrm{~b}$ & $15.27 \mathrm{~b}$ & $15.65 b$ & $16.80 \mathrm{a}$ \\
\hline 5 Buku & $4.95 b$ & $16.17 \mathrm{a}$ & $18.47 \mathrm{a}$ & $19.30 \mathrm{a}$ & $19.07 \mathrm{a}$ \\
\hline
\end{tabular}

keterangan : angka yang diikuti oleh huruf yang sama pada kolom yang sama tidak berbeda nyata pada uji lanjut DMRT 5\%.

Tabel 5 menunjukkan perbedaan varietas berpengaruh terhadap panjang cabang primer pada umur 3 MST dan 4 MST, namun pada 7 MST perbedaan tersebut menjadi tidak nyata. Hal ini menunjukkan bahwa laju pertumbuhan panjang cabang primer antar kedua varietas relatif sama. Panjang cabang primer pada varietas ungu cenderung lebih panjang dibandingkan varietas cilembu.

Tabel 5. Pengaruh varietas terhadap panjang cabang primer

\begin{tabular}{|c|c|c|c|c|c|}
\hline \multirow{2}{*}{ Varietas } & \multicolumn{5}{|c|}{ Umur } \\
\hline & $3 \mathrm{MST}$ & $4 \mathrm{MST}$ & $5 \mathrm{MST}$ & $6 \mathrm{MST}$ & 7 MST \\
\hline Cilembu & $4.47 \mathrm{~b}$ & $12.13 b$ & $14.91 \mathrm{a}$ & $16.09 \mathrm{a}$ & $16.47 \mathrm{a}$ \\
\hline Ungu & $6.79 \mathrm{a}$ & $14.62 \mathrm{a}$ & $16.25 \mathrm{a}$ & $16.28 \mathrm{a}$ & $16.80 \mathrm{a}$ \\
\hline
\end{tabular}

keterangan : angka yang diikuti oleh huruf yang sama pada kolom yang sama tidak berbeda nyata pada uji lanjut DMRT 5\%.

Panjang Cabang Sekunder. Cabang sekunder adalah cabang yang tumbuh pada cabang primer dan berasal dari tunas sekunder. Panjang cabang sekunder diukur dari tempat tumbuh 
batang sekunder sampai ujung cabang sekunder. Tabel 6 menunjukkan bahwa pertumbuhan panjang cabang sekunder berbeda nyata pada umur 5 MST, 6 MST, dan 7 MST. Umur 5 MST sampai 7 MST laju pertumbuhan panjang cabang sekunder varietas cilembu nyata lebih lambat diabngkan varietas ungu. meskipun selisihnya tidak terlalu besar.

Tabel 6. Pengaruh varietas terhadap panjang cabang sekunder

\begin{tabular}{|c|c|c|c|c|c|}
\hline \multirow{2}{*}{ Varietas } & \multicolumn{5}{|c|}{ Umur } \\
\hline & $3 \mathrm{MST}$ & $4 \mathrm{MST}$ & $5 \mathrm{MST}$ & $6 \mathrm{MST}$ & $7 \mathrm{MST}$ \\
\hline Cilembu & 209 & 327 & $307 \mathrm{~h}$ & cm------ & $576 \mathrm{~h}$ \\
\hline Ungu & $2.48 \mathrm{a}$ & $2.70 \mathrm{a}$ & $4.00 \mathrm{a}$ & $5.83 \mathrm{a}$ & $7.93 \mathrm{a}$ \\
\hline
\end{tabular}

keterangan : angka yang diikuti oleh huruf yang sama pada kolom yang sama tidak berbeda nyata pada uji lanjut DMRT 5\%.

Jumlah Cabang Primer. Jumlah cabang primer diamati banyaknya cabang yang tumbuh dari buku cabang primer. Tabel 7 menunjukkan bahwa pertumbuhan jumlah cabang primer pada 3 MST, 4 MST, dan 6 MST berbeda nyata. Pertumbuhan jumlah cabang primer pada umur 3 MST, 4 MST dan 6 MST berbeda nyata namun pada 7 MST menjadi tidak berbeda nyata. Hal ini mengindikasikan bahwa jumlah cabang primer kedua varietas relatif sama. Pada 7 MST terjadi penurunan jumlah cabang primer, hal ini diduga karena terdapatnya cabang tua yang mengering dan mati. Keseimbangan antara munculnya tunas baru dengan mengeringnya cabang tua tidak setara sehingga cabang ubijalar mengalami fluktuasi (Junaedi, 2005).

Tabel 7. Pengaruh varietas terhadap jumlah cabang primer

\begin{tabular}{cccccc}
\hline \multirow{2}{*}{ Varietas } & \multicolumn{5}{c}{ Umur } \\
\cline { 2 - 5 } & 3 MST & 4 MST & 5 MST & 6 MST & MST \\
\hline \multirow{2}{*}{ Cilembu } & $2.47 \mathrm{~b}$ & $2.91 \mathrm{~b}$ & $5.42 \mathrm{a}$ & $5.33 \mathrm{a}$ & $3.44 \mathrm{a}$ \\
Ungu & $3.44 \mathrm{a}$ & $3.82 \mathrm{a}$ & $4.58 \mathrm{a}$ & $4.00 \mathrm{~b}$ & $2.93 \mathrm{a}$
\end{tabular}

keterangan : angka yang diikuti oleh huruf yang sama pada kolom yang sama tidak berbeda nyata pada uji lanjut DMRT 5\%.

Jumlah Cabang Sekunder. Jumlah cabang sekunder yang diamati adalah banyaknya cabang yang tumbuh dari buku cabang sekunder. Tabel 8 menunjukkan bahwa perlakuan 3 buku tidak berbeda nyata dengan perlakuan 4 buku, dan 5 buku pada setiap minggu.

Tabel 8. Pengaruh jumlah buku terhadap jumlah cabang sekunder

\begin{tabular}{|c|c|c|c|c|c|}
\hline \multirow{2}{*}{ Jumlah Buku } & \multicolumn{5}{|c|}{ Umur } \\
\hline & $3 \mathrm{MST}$ & $4 \mathrm{MST}$ & $5 \mathrm{MST}$ & $6 \mathrm{MST}$ & $7 \mathrm{MST}$ \\
\hline & & & --------ce & tanaman & - \\
\hline 3 Buku & $5.73 a$ & $8.13 \mathrm{a}$ & $10.17 \mathrm{a}$ & $15.13 \mathrm{a}$ & $21.47 \mathrm{a}$ \\
\hline 4 Buku & $7.77 \mathrm{a}$ & $11.77 \mathrm{a}$ & $14.07 \mathrm{a}$ & $17.60 \mathrm{a}$ & $22.30 \mathrm{a}$ \\
\hline 5 Buku & $6.47 \mathrm{a}$ & $9.60 \mathrm{a}$ & $12.10 \mathrm{a}$ & $13.03 \mathrm{a}$ & $23.27 \mathrm{a}$ \\
\hline
\end{tabular}

keterangan : angka yang diikuti oleh huruf yang sama pada kolom yang sama tidak berbeda nyata pada uji lanjut DMRT 5\%.

Tabel 9 menunjukkan bahwa varietas cilembu dan ungu tidak berbeda nyata pada setiap minggunya. Hal ini menunjukkan varietas cilembu dan ungu cenderung menghasilkan jumlah cabang sekunder yang relatif sama.

Tabel 9. Pengaruh varietas terhadap jumlah cabang sekunder

\begin{tabular}{cccccc}
\hline \multirow{2}{*}{ Varietas } & \multicolumn{5}{c}{ Umur } \\
\cline { 2 - 6 } & 3 MST & 4 MST & 5 MST & 6 MST & 7 MST \\
\hline \multirow{2}{*}{ Cilembu } & $6.44 \mathrm{a}$ & $-9.78 \mathrm{a}$ & $11.64 \mathrm{a}$ & $13.80 \mathrm{a}$ & $23.47 \mathrm{a}$ \\
Ungu & $6.87 \mathrm{a}$ & $9.89 \mathrm{a}$ & $12.58 \mathrm{a}$ & $16.71 \mathrm{a}$ & $21.22 \mathrm{a}$ \\
\hline
\end{tabular}

keterangan : angka yang diikuti oleh huruf yang sama pada kolom yang sama tidak berbeda nyata pada uji lanjut DMRT 5\%. 


\section{Evaluiasi terhadap Komnopep produksi}

Panen bibit $25 \mathrm{~cm}, 20 \mathrm{~cm}$, dan $15 \mathrm{~cm}$. Panen bibit dilakukan dengan mengelompokkan stek menjadi 3 ukuran yaitu bibit berukuran 25 $\mathrm{cm}$, bibit berukuran $20 \mathrm{~cm}$, dan bibit berukuran 15 $\mathrm{cm}$. Pada umumnya, panjang stek yang biasa ditanam berukuran $25 \mathrm{~cm}$. Menurut Hartmann et al. (1997) menyatakan bahwa panjang stek berpengaruh terhadap pertumbuhan akar dan tunas. Semakin panjang stek yang dihasilkan, maka pertumbuhan tunas akan meningkat. Panjang stek juga mempengaruhi jumlah ruas dan jumlah buku. Menurut Santoso et al. (2008) perbanyakan tanaman jarak pagar secara vegetatif dapat dilakukan dengan menggunakan stek batang berukuran panjang berkisar 20-30 cm. Penggunaan stek panjang memerlukan bahan tanam yang lebih banyak. Stek yang panjang ratarata memiliki jumlah buku yang banyak. Menurut Santoso (2009) menyatakan bahwa panjang stek terkait dengan ketersediaan cadangan makanan yang umumnya berupa karbohidrat, semakin rendah cadangan makanan maka semakin pendek ukuran stek. Potensi cadangan makanan yang dimiliki masing-masing stek akan menentukan pertumbuhan dan perkembangan bibit.

Hasil rekapitulasi sidik ragam menunjukkan bahwa jumlah buku tidak berpengaruh terhadap peubah jumlah bibit ukuran $25 \mathrm{~cm}, 20 \mathrm{~cm}$, dan $15 \mathrm{~cm}$. Hal ini mengindikasikan bahwa perlakuan 3 buku, 4 buku, dan 5 buku menghasilkan jumlah bibit yang relatif sama. Menurut Santoso, et al (2008) Panjang stek jarak pagar berkisar 20-30 cm tidak berpengaruh nyata terhadap jumlah tunas bibit. Menurut Marleni (2010) menunjukkan bahwa jumlah buku yang lebih banyak cenderung memiliki jumlah tunas yang hidup lebih banyak. Tunas yang lebih banyak memerlukan lebih banyak hasil asimilasi untuk pertumbuhan tunas tersebut.

Tabel 10. Pengaruh jumlah buku terhadap peubah jumlah bibit $25 \mathrm{~cm}, 20 \mathrm{~cm}$, dan $15 \mathrm{~cm}$

\begin{tabular}{cccc}
\hline \multirow{2}{*}{ Jumlah Buku } & Bibit $25 \mathrm{~cm}$ & Bibit 20 cm & Bibit 15 cm \\
\cline { 2 - 4 } & $11.05 \mathrm{a}$ & $7.29 \mathrm{a}$ & $7.22 \mathrm{a}$ \\
3 Buku & $11.67 \mathrm{a}$ & $7.58 \mathrm{a}$ & $6.66 \mathrm{a}$ \\
$5 \mathrm{Buku}$ & $9.73 \mathrm{a}$ & $7.19 \mathrm{a}$ & $6.63 \mathrm{a}$ \\
\hline
\end{tabular}

keterangan : angka yang diikuti oleh huruf yang sama pada kolom yang sama tidak berbeda nyata pada uji lanjut DMRT $5 \%$.

Tabel 11 menunjukkan bahwa perbedaan antar varietas berpengaruh terhadap hasil panen bibit berukuran $20 \mathrm{~cm}$. Hasil panen bibit $20 \mathrm{~cm}$ menunjukkan bahwa bibit varietas ungu memiliki hasil panen bibit tertinggi yaitu 8 stek dibandingkan dengan bibit varietas Cilembu yang hanya 6 stek. Varietas yang lebih banyak menghasilkan bibit pada panen bibit berukuran 20 $\mathrm{cm}$ ini yaitu varietas Ungu. Bibit varietas Ungu menghasilkan jumlah cabang yang lebih banyak dan menghasilkan jumlah buku lebih banyak. Hal ini menyebabkan varietas Ungu paling banyak menghasilkan jumlah bibit. Semakin tinggi panjang batang yang dihasilkan, maka tunas yang dihasilkan juga akan semakin meningkat. Hal ini mengindikasikan bahwa varietas dengan panjang batang yang lebih panjang dapat menghasilkan jumlah bibit yang lebih banyak.

Tabel 11. Pengaruh varietas terhadap peubah jumlah bibit $25 \mathrm{~cm}, 20 \mathrm{~cm}$, dan $15 \mathrm{~cm}$

\begin{tabular}{|c|c|c|c|}
\hline \multirow{2}{*}{ Varietas } & Bibit $25 \mathrm{~cm}$ & Bibit $20 \mathrm{~cm}$ & Bibit $15 \mathrm{~cm}$ \\
\hline & \multicolumn{3}{|c|}{-------------------------stek/tanaman--------------------- } \\
\hline Cilembu & $11.50 \mathrm{a}$ & $6.22 \mathrm{~b}$ & $6.80 \mathrm{a}$ \\
\hline Ungu & $10.12 \mathrm{a}$ & $8.48 \mathrm{a}$ & $6.88 \mathrm{a}$ \\
\hline
\end{tabular}

keterangan : angka yang diikuti oleh huruf yang sama pada kolom yang sama tidak berbeda nyata pada uji lanjut DMRT 5\%.

Gambar 1 menunjukkan bahwa varietas cilembu memiliki jumlah bibit yang semakin meningkat pada perlakuan 4 buku dan ketika pada perlakuan 5 buku, jumlah bibit menurun. Beda halnya dengan varietas ungu yang cenderung menghasilkan jumlah bibit yang menurun pada perlakuan 4 buku tetapi stabil pada perlakuan 5 buku. 


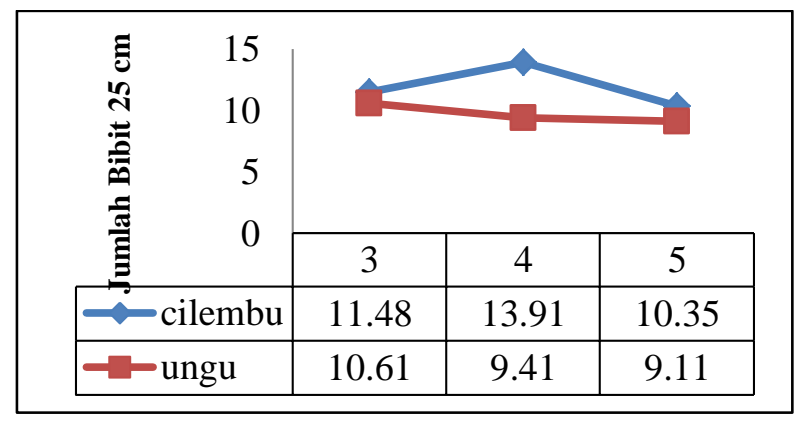

Gambar 1. Interaksi jumlah buku dan varietas terhadap jumlah bibit ukuran $25 \mathrm{~cm}$

Bobot Umbi Total per Petak. Komponen hasil umbi yang dihasilkan antara lain peubah bobot umbi total per petak. Bobot umbi total per petak didapatkan dengan menimbang bobot umbi pada setiap tanaman contoh dan tanaman petak. Tabel 12 menunjukkan bahwa bobot umbi total perlakuan 3 buku maupun varietas ungu menghasilkan bobot umbi total yaitu 0,82 $\mathrm{kg} /$ petak atau setara dengan 1.025 ton/ha. Menurut data BPS (2012) hasil produksi umbi nasional pada tahun 2015 mencapai 20 ton/ha, hal ini dapat dibuktikan bahwa hasil produksi umbi masih sangat jauh dari hasil produksi umbi nasional.

Hal yang menyebabkan produksi umbi rendah yaitu dosis pupuk $\mathrm{KCl}$ yang digunakan rendah, karna penelitian ini menggunakan pupuk urea yang lebih banyak untuk pertumbuhan vegetatif. Selain itu, pada saat awal panen, batang sudah di panen terlebih dahulu sebagai bibit. Menurut Harjadi (2000) menyatakan bahwa rendahnya produksi bisa terjadi karena faktor tanaman itu sendiri, fase pertumbuhan ubi jalar didominasi pada pertumbuhan vegetatif yang menyebabkan pertumbuhan vegetatif berlebihan dan dengan bersamaan kurangnya pembentukan umbi. Akibatnya sedikit sekali karbohidrat yang tersisa untuk perkembangan umbi. Fase vegetatif dan reproduktif yang tidak seimbang serta penggunaan dan pemupukan yang tidak seimbang menyebabkan karbohidrat yang terdapat pada umbi sedikit.

Tabel 12. Pengaruh jumlah buku dan varietas terhadap peubah bobot umbi total per petak

\begin{tabular}{cccc}
\hline \multirow{2}{*}{ Jumlah Buku } & \multicolumn{2}{c}{ Varietas } & Rataan \\
\cline { 2 - 3 } & Cilembu & Ungu & \\
3 Buku & 0.73 & 0.82 & $0.77 \mathrm{a}$ \\
4 Buku & 0.76 & 0.75 & $0.76 \mathrm{a}$ \\
5 Buku & 0.73 & 0.74 & $0.74 \mathrm{a}$ \\
Rataan & $0.74 \mathrm{a}$ & $0.77 \mathrm{a}$ & \\
\hline
\end{tabular}

keterangan : angka yang diikuti oleh huruf yang sama pada kolom yang sama tidak berbeda nyata pada uji lanjut DMRT 5\%.

\section{Analisis Korelasi}

Koefisien korelasi Pearson digunakan untuk mengukur kekuatan dan arah hubungan linier dari dua veriabel. Dua variabel dikatakan berkorelasi apabila perubahan salah satu variabel disertai dengan perubahan variabel lainnya, baik dalam arah yang sama ataupun arah yang sebaliknya. Nilai korelasi berkisar antara 1 sampai -1 , nilai semakin mendekati 1 atau -1 berarti hubungan antara dua variabel semakin kuat.

Tabel 13. Hasil rekapitulasi analisis korelasi

\begin{tabular}{ccccccc}
\hline \multicolumn{1}{c}{ PB } & PCP & PCS & JCP & JCS & UT \\
\hline PCP & $0,960^{\text {tn }}$ & & & & & \\
PCS & $-0,173^{\text {tn }}$ & $-0,055^{\text {tn }}$ & & & & \\
JCP & $0,163^{\text {tn }}$ & $0,299^{\text {tn }}$ & $0,591^{* *}$ & & \\
JCS & $-0,019^{\text {tn }}$ & $-0,044^{\text {tn }}$ & $0,431^{*}$ & $0,073^{\text {tn }}$ & & \\
UT & $0,069^{\text {tn }}$ & $0,123^{\text {tn }}$ & $-0,115^{\text {tn }}$ & $-0,074^{\text {tn }}$ & $0,166^{\text {tn }}$ & \\
JB25 & $-0,587^{* *}$ & $-0,574^{* *}$ & $0,461^{*}$ & $0,246^{\text {tn }}$ & $0,341^{\text {tn }}$ & $-0,158^{\text {tn }}$ \\
\hline
\end{tabular}

Keterangan : PB : Panjang Batang; PCP : Panjang Cabang Primer; PCS : Panjang Cabang Sekunder; JCP : Jumlah Cabang Primer; JCS : Jumlah Cabang Sekunder; UT : Umbi Total; JB25 : Bibit berukuran $25 \mathrm{~cm}$.

Berdasarkan hasil uji korelasi pada Tabel 13, menunjukkan bahwa panjang batang berkorelasi dengan jumlah bibit $25 \mathrm{~cm}$ yang menunjukkan meningkatnya panjang batang akan mempengaruhi jumlah bibit yang berukuran 25 $\mathrm{cm}$. Panjang cabang primer berkorelasi dengan jumlah bibit $25 \mathrm{~cm}$ yang menunjukkan bahwa meningkatnya panjang cabang primer akan mempengaruhi jumlah bibit yang berukuran 25 $\mathrm{cm}$. Panjang cabang sekunder berkorelasi dengan 
jumlah cabang primer, berkorelasi dengan jumlah cabang sekunder, dan jumlah bibit berukuran 25 $\mathrm{cm}$. Jumlah cabang primer, jumlah cabang sekunder, dan bobot umbi total tidak mempunyai hubungan korelasi dengan peubah yang lain. Hal ini menunjukkan hubungan antar variabel yang lemah dan tidak berkorelasi positif.

\section{KESIMPULAN}

Perlakuan jumlah buku yang berbeda ternyata menghasilkan jumlah stek yang relative sama. Varietas Ungu menghasilkan jumlah cabang sekunder lebih panjang dari pada Cilembu namun jumlah stek yang dihasilkan oleh varietas Ungu dan Cilembu relatif sama. Kebun yang dikhususkan untuk produksi bibit menghasilkan produksi umbi.yang rendah (1 $025 \mathrm{t} / \mathrm{ha}$ ).

\section{DAFTAR PUSTAKA}

[BPS] Badan Pusat Statistik. 2015. Produksi Ubi Jalar Menurut Provinsi. [internet]. [diunduh 2016 Sept 08]. Tersedia pada http://www.bps.go.id/.

Gomez, K.A., Gomez A.A. 2007. Prosedur Statistik untuk Penelitian Pertanian. Jakarta (ID): UI Press.

Harjadi, S.S. 2000. Pengantar agronomi. Jakarta (ID): PT Gramedia Pustaka Utama.

Harjadi, M.M.S.S. 1996. Pengantar Agronomi. Jakarta (ID): PT Gramedia Pustaka.

Hartmann, H.T., D.E. Kester,. F.T. Davies, R.L. Geneve. 1997. Plant Propagation. Principles and Practices (8th edition).Prentice hall. New York.

Junaedi E. 2005. Pengaruh pupuk N-P-K terhadap status Nitrat dan Kalium tajuk serta pertumbuhan dan produksi ubi jalar (Ipomoea batatas (L) Lam). [Skripsi]. Jurusan Budidaya Pertanian, Faperta IPB.
Kay, D.E. 1973. Tpi Crop and Product Digest. The Tropical Products Institute, Foreign and Commonwealth Office Overseas Development Aministration.

Marleni. 2010. Pengaruh Umur Pohon Tetua dan Jumlah Buku Stek Cabang terhadap Pertumbuhan Bibit Jarak Pagar (Jatropha curcas L.). [Skripsi]. Departemen Agronomi dan Hortikultura, Faperta IPB.

Santoso, B.B., Nasnam, Hariyadi, Susanto, S., Purwoko, B.S. 2008. Perbanyakan vegetatif tanaman jarak pagar (Jatropha curcas L.) dengan stek batang: pengaruh panjang dan diameter stek. Bul. Agron. 36(3): 255-262.

Santoso, B.B. 2009. Karakterisasi Morfo-Ekotipe dan Kajian Beberapa Aspek Agronomi Jarak Pagar (Jatropha curcas L.) di Nusa Tenggara Barat.[Disertasi]. Program Pasca Sarjana, Institut Pertanian Bogor.

Soemarno 1985. Pengaruh dosis dan waktu pemberian pupuk Urea pada tanah aluvial dan mediteran terhadap pertumbuhan dan produksi ubi jalar varietas Lokal Grompol dan Unggul Daya. [Skripsi]. Universitas Brawijaya. Malang.

Suparman. 2007. Bercocok Tanam Ubi Jalar. Jakarta (ID): Azka Mulia Media.

Tinuk, S.W. 2012. Keragaan pertumbuhan dan hasil umbi beberapa varietas unggul ubijalar pada dua cara tanam. Prosiding Seminar Hasil Penelitian Tanaman Aneka Kacang dan Umbi.

Wargiono, J. 2007. Penuntun Bercocok Tanam Ubi Jalar. Buletin Penataran PPS Bidang Agronomi dan Pola Pertanaman. Puslitbangtan Bogor. 